\title{
Manuskrip Keagamaan di Masjid Popongan: Kajian Kodikologi dan Pemetaan Isi
}

\author{
Islah Gusmian \\ IAIN Surakarta \\ email: islahgusmian@gmail.com
}

\begin{abstract}
This article examines religious manuscripts stored in the Popongan mosque, Klaten, Central Java. As a preliminary study, this article describes the physical aspects of the manuscript as well as mapping the topics contained therein. The approach used is philology and historical perspective in it.As a manuscript that was born in a pesantren community, the Popongan mosque manuscript reflects the struggle of students and scholars in the process of learning and transmission of Islamic scholarship in the late 19th century AD. This study indicates that pesantren have taken an important role in the practice of Islamic learning and at the same time as an important subject in the history of islamization in the archipelago.
\end{abstract}

\section{Keywords:}

manuscript, pesantren, Popongan, philology

\begin{abstract}
Abstrak
Artikel ini mengkaji tentang manuskrip keagamaan yang disimpan di masjid Popongan, Klaten, Jawa Tengah. Sebagai kajian awal, artikel ini mendeskripsikan aspek-aspek fisik manuskrip serta pemetaan topik-topik yang ada di dalamnya. Pendekatan yang dipakai adalah filologi serta perspekstif sejarah yang ada di dalamnya. Sebagai manuskrip yang lahir di tengah masyarakat pesantren, manuskrip masjid Popongan mencerminkan tentang pergulatan santri dan kiai dalam proses pembelajaran dan transmisi keilmuan Islam pada era akhir abad $19 \mathrm{M}$. Melalui manuskrip-manuskrip masjid Popongan tersebut kita bisa melihat keragaman bidang ilmu yang dikaji para santri dan metode pembelajarannya. Di sinilah bahwa pesantren telah mengambil peran penting dalam praktik pembelajaran Islam dan sekaligus sebagai subjek penting dalam sejarah islamisasi di Nusantara.
\end{abstract}

\section{Kata Kunci:}

manuscript, pesantren, Popongan, philology 


\section{Pendahuluan}

Manuskrip merupakan salah satu warisan budaya, yang dalam konteks sejarah dan peradaban, memiliki posisi penting. Di dalamnya terdapat teks yang ditulis dengan aksara dan bahasa yang beragam, serta dari sisi isi, terdapat beragam gagasan, pemikiran, kreativitas, tradisi, keyakinan, dan kearifan yang hidup di masa lalu. Melalui manuskrip, kita mengetahui tentang sejarah bangsa dan peradaban serta beragam kearifan yang diwariskan suatu bangsa dari masa ke masa. Hal-hal yang demikian, dalam kadar tertentu, memiliki relevansi dengan konteks dan sejarah di masa sekarang.

Sebagai bangsa yang ditakdirkan memiliki basis sosial yang beragam, Indonesia memiliki warisan manuskrip yang jumlahnya sangat fantastis. Dalam konteks manuskrip keislaman, misalnya, di Perpustakaan Nasional Republik Indonesia Jakarta, mengacu catatan Berg (1873) dan Ronkel (1913), terdapat tidak kurang dari 1000 manuskrip berbahasa Arab. Di Dayah Tanoh Abee, Seulimeum, Aceh, mengacu pada catatan Abdullah dan M. Dahlan (1980), terdapat tidak kurang dari 400 manuskrip. Di luar wilayah Indonesia, manuskrip-manuskrip berbahasa Arab yang berasal dari Nusantara terdapat antara lain di Universiteits Bibliotheek, Leiden, Belanda, yaitu sekitar 5000 buah manuskrip berbahasa Arab-jumlah ini mengacu pada penghitungan Voorhoeve (1957); di Malaysia, meskipun bercampur dengan bahasa Melayu, mengacu pada catatan Ibrahim Ismail dan Osman Bakar (1992), terdapat sekitar 700-an manuskrip berbahasa Arab. Manuskrip tersebut sekarang disimpan di Museum Islam Kuala Lumpur, Malaysia (Gusmian 2015: Bagian 6).

Jumlah di atas belum termasuk manuskrip-manuskrip yang berada dalam kepemilikan pribadi yang tersebar di masyarakat serta yang disimpan di berbagai tempat ibadah, seperti masjid, musala, langgar, dayah, dan lembaga pendidikan seperti pesantren. Di tempat ibadah dan pesantren tersebut, mulai dari daerah Aceh, Riau, Palembang, Banten, Cirebon, 
Yogyakarta, Surakarta, Lombok, hingga Madura, kita menemukan warisan manuskrip yang jumlahnya sangat banyak. Masjid di kompleks Pesantren al-Manshur, Popongan, Klaten, Jawa Tengah termasuk salah satu tempat ibadah yang di dalamnya tersimpan manuskrip keislaman tersebut.

Manuskrip-manuskrip tersebut ditulis oleh para ulama di Surakarta, di antaranya adalah K.H. Muhammad Muqri, menantu pendiri pesantren Popongan, K.H. Muhammad Manshur. Selain itu, terdapat pula teks-teks salinan dari karya ulama Timur Tengah. Manuskrip-manuskrip tersebut, sebagaimana tampak dari informasi eksternal maupun internal yang ada dalam manuskrip, isi dan bentuknya sangat beragam. Dari sisi isi, manuskrip-manuskrip tersebut terdiri dari berbagai bidang ilmu, seperti fikih, kalam, tasawuf, ilmu gramatika bahasa Arab, mushaf Al-Qur'an, primbon, dan kumpulan doa. Dari sisi bentuk, ada manuskrip yang ditulis dengan model syair (nadam) dan ada yang dengan model prosa. Adapun dari sisi bahasa dan aksara, manuskrip-manuskrip tersebut ditulis dengan bahasa Arab, Jawa, Melayu, dan dengan memakai aksara Arab, Latin, serta Pegon.

Pada tahun 2016, manuskrip di masjid Popongan ini-selanjutnya disebut manuskrip masjid Popongan-telah didigitalisasi oleh Pusat Kajian Naskah dan Khazanah Islam Nusantara bekerjasama dengan Pusat Penelitian dan Pengembangan Lektur dan Khazanah Keagamaan Kementerian Agama Republik Indonesia, dimana di dalamnya penulis ikut terlibat. Versi digitalnya telah diunggah di web Kementerian Agama Republik Indonesia pada tahun 2017. Secara pragmatik, artikel ini akan mendeskripsikan manuskrip-manuskrip Popongan tersebut, baik dari sisi isi, bentuk, alas, bahasa, dan aksara yang digunakan. Upaya semacam ini penting dalam rangka memberikan peta awal mengenai keragaman dan karakteristik manuskrip masjid Popongan tersebut, yang secara akademik bisa difungsikan sebagai data sejarah kebudayaan, terutama sejarah pesantren Popongan dan masyarakat Islam di Surakarta, serta untuk 
mengungkap visi keilmuan dan ideologi pesantren di wilayah Jawa Tengah era akhir tahun 1900.

Untuk memperoleh hal-hal yang dimaksud, dalam tulisan ini dipakai pendekatan kodikologi dan tekstologi (Siti Baroroh Baried 1985: 5); (Sardjoko 2007). Keduanya dipakai untuk menjelaskan kondisi fisik manuskrip serta gagasan-gagasan yang terkandung di dalamnya. Gagasangagasan yang dimaksud adalah terkait dengan pemakaian isi, topik, dan aneka bidang keilmuan yang ada di dalamnya. Langkah ini dipilih untuk mengungkap aspek-aspek umum yang menjadi corak dari manuskrip masjid Popongan (Sardjoko 2007: 69).

\section{Manuskrip dan Peradaban Islam Nusantara}

Manuskrip bukanlah sekadar karya sastra. Ia juga bisa didekati dan difungsikan dari banyak sisi, terutama dari sisi sejarah dan peradaban. Banyak hal bisa digali dan ditemukan dari dalam manuskrip, yaitu halhal yang berkaitan dengan kearifan lokal, kreativitas, ide, strategi dakwah dan perjuangan, pola kehidupan, dan perkembangan pemikiran dan keagamaan. Strategi perjuangan melawan kolonial Belanda yang dilakukan oleh para ulama di Nusantara, misalnya, bisa ditemukan dalam teks-teks yang ditulis oleh K.H. Ahmad Rifa'i Kalisalak. ${ }^{1}$

Dalam isu-isu yang berkaitan dengan akulturasi, adopsi dan adaptasi antara nilai-nilai Islam dan budaya Jawa bisa ditemukan dalam berbagai manuskrip primbon dan pengobatan yang ada di Jawa. Dalam khazanah kesusastraan Jawa, teks primbon ditemukan dalam berbagai versi, varian, dan ragam. Keragaman tersebut diacukan pada konteks isi dan kegunaannya. Menurut Girardet, di wilayah Surakarta, ditemukan setidaknya 25 macam

1 Kiai Ahmad Rifa'i hidup pada era abad ke 18 M. Namanya direkam dalam Serat Cebolek secara pejoratif, karena sikap penentangannya kepada penguasa lokal yang berkomplot dengan penjajah. Bentuk penentangannya bisa ditemukan dalam manuskrip berjudul Tabyin al-Islah, dan strategi dakwahnya bisa ditemukan misalnya dalam karyanya berjudul Tabsirah.

DINIKA, Volume 4, Number 2, May - August 2019 
Primbon, yang kesemuanya itu mencerminkan keragaman isi dan kegunaannya (Girardet 1983). Dalam tradisi Islam, dikenal khazanah mujarabat $^{2}$ yang juga hidup dalam dinamika dan keragaman unsur yang dimilikinya (Gusmian 2004: 29-36).

Sejarah, gerakan, dan pemikiran Wali Songo, misalnya, bisa ditemukan dalam teks Nasehat Seh Bari yang ditulis oleh Sunan Bonang (1465-1525 M) (Drewes 1969). Teks ini berisi nasihat tentang gabungan antara ilmu ushuluddin, tasawuf, dan fiqih. Teks ini menjadi bahan kajian B.J.O. Schrieke pada 1916 dan J.G.H. Gunning pada 1881 M di Universitas Leiden, dan kemudian menjadi rujukan kajian Kraemer pada 1921 M di Universitas yang sama (Saksono 1995).

Dari kajian tersebut ditemukan bahwa bahan rujukan teks tersebut di antaranya adalah Ibya' al- 'Ulum al-Din karya Imam al-Ghazali, Tambid fi Bayan al-Taubid karya Abu Syakur bin Syu'aib al-Kasi al-Hanafi al-Salimi (hidup pada akhir abad ke-5 H), dan Al-Risalah al-Makkiyah fi Tariq alSada al-Sufyyyah karya 'Afifuddin al-Tamimi. Di dalam teks ini, paham bulul dan wahdah al-wujud ditolak dan ditegaskan bahwa Allah hanya bisa dilihat dengan mata kepala ketika di akhirat, itu pun tergantung dengan martabat manusia dalam mencapai suluk (Saksono 1995).

Dari penjelasan di atas, kita mengerti bahwa secara paradigmatik, manuskrip merupakan karya yang di dalamnya terdapat ide, gagasan, kearifan masa lalu, dan strategi kebudayaan. Hal-hal yang demikian, pada unsur-unsur tertentu mempunyai relevansi dengan konteks kehidupan dan problematika di masa kini. Oleh karena itu, melalui manuskrip, kita bisa mengambil kearifan dan memanfaatkannya sebagai sumber inspirasi dalam menghadapi masalah-masalah yang terjadi di masa kini.

2 Kata mujarabat berasal dari bahasa Arab, mujarrabat. Artinya 'menguij' atau 'mencoba'. Secara bahasa, ia dipahami sebagai segala sesuatu yang telah diuji-dicoba atau telah dilakukan eksperimen. 


\section{Sejarah Masjid Popongan dan Penyimpanan Manuskrip}

Masjid Popongan berada di komplek pesantren Al-Manshur di desa Popongan, Tegalgondo, Wonosari, Klaten, Jawa Tengah. Pesantren ini didirikan oleh K.H. Muhammad Manshur (1858-1955M)³ — selanjutnya disebut Mbah Manshur ${ }^{4}$ - putera Syaikh Muhammad Abdul Hadi Giri Kusumo, seorang mursyid tarekat Naqsyabandiyah Khalidiyah di Giri Kusumo, Mranggen, Demak, Jawa Tengah. Pada awalnya, nama pesantren tersebut adalah Pesantren Popongan. Nama ini diambil dari nama dusun tempat pesantren tersebut didirikan. Popongan adalah nama dusun di Kelurahan Tegalgondo Kecamatan Wonosari Kabupaten Klaten. Dusun ini terletak di Jalan Solo-Yogyakarta, KM 8 Delanggu; sebuah dusun kecil yang sebagian penduduknya bekerja sebagai petani.

Pesantren Popongan didirikan pada tahun 1926 oleh Mbah Manshur bersamaan dengan pembangunan masjid di komplek pesantren tersebut. Tahun pendirian ini ditulis dalam sebuah prasasti yang berada di atas mihrab masjid. Lima dekade kemudian, yaitu pada 21 Juni 1980, nama Pesantren Popongan diganti menjadi Pesantren Al-Mansur. Penggantian ini untuk mengenang peran dan jasa Mbah Manshur dalam dunia pendidikan dan tarekat-meskipun sebagian masyarakat hingga kini seringkali masih menyebutnya dengan "Pesantren Popongan".

Sebelum tinggal di Popongan, Mbah Manshur belajar di Pesantren Jamsaren Surakarta di bawah asuhan K.H. Idris. Keberadaannya di Klaten disebabkan faktor pernikahan, yaitu sejak ia menikah dengan Nyai Maryam, putra K.H. Fadlil, seorang kiai dan pedagang kaya, pada tahun

3 Mengacu pada satu dokumen yang ditulis dengan aksara Pegon yang tersimpan di dalam satu kitab Dala'il al-Khairat di masjid Popongan, Mbah Manshur lahir pada pukul 15.00, Rabu Pon, 17 Maulid, $1292 \mathrm{H}$ dan wafat pada pukul 04.25, Ahad Pon, Maulid, 1955 M. Bila dialihkan ke tahun Masehi, ia lahir pada 3 Desember 1858 adapun kematiannnya adalah 1 Agustus 1955.

4 Panggilan 'Mbah' di masyarakat Pesantren di Jawa seringkali digunakan untuk menunjukkan kearifan, kesenioran, dan kemendalaman seseorang dalam masalah pengetahuan keagamaan dan posisi spiritualitasnya yang tinggi. Dalam konteks pengertian semacam itu, panggilan "Mbah" dipakai dalam tulisan ini.

DINIKA, Volume 4, Number 2, May - August 2019 
1918. Sebagai anak muda yang telah mengalami proses pendidikan agama yang lama di pesantren, oleh K.H. Fadlil ia diminta mengajarkan agama Islam kepada masyarakat yang tinggal di Popongan. Di situlah kemudian sebagai cikal bakal pendirian Pesantren Popongan.

Selain mengajar ilmu agama Islam, Mbah Manshur juga mengembangkan tarekat Naqshabandiyah di Popongan dan di berbagai daerah lain melalui para badal, dan di antara mereka ada yang telah menjadi mursyid. Mereka ini adalah Kiai Arwani (Kudus), Kiai Abdul Mi'raj (Candisari, Demak), serta cucunya sendiri, KH Salman Dahlawi (Klaten) (Bruinessen 1992: 166). Di Solo, Mbah Manshur mempunyai rumah yang dimanfaatkan untuk pengembangan tarekat Naqsyabandiyah. Di sini, Mbah Manshur dibantu oleh seorang murid perempuan, yaitu Nyai Muharromah (Nyai Soelomo Resoatmodjo).

Setelah Mbah Manshur wafat, khususnya di bidang tarekat, perjuangannya diteruskan oleh cucunya, yaitu K.H. Salman Dahlawi (19362013) — selanjutnya disebut Mbah Salman. Mbah Salman adalah putra dari pasangan K.H. Muhammad Muqri bin Kafrawi (Tegalsari, Solo) dan Hj. Masyfu'ah binti Manshur. Ia belajar ilmu agama di berbagai pesantren di Jawa, di antaranya di Pesantren Al-Muayyad Mangkuyudan Surakarta di bawah asuhan K.H. Ahmad Umar Abdul Mannan; di Pesantren Bendo, Pare, Kediri, Jawa Timur di bawah asuhan K.H. Khozin; di Madrasah Mamba'oel Oeloem dan Madrasah Soennijah Keprabon Surakarta; dan pernah nyantri posonan ${ }^{5}$ kepada K.H. Ahmad Dalhar Watucongol, Magelang, Jawa Tengah. Selain berguru kepada ulama di Jawa, Mbah Salman juga berguru kepada Sayyid Muhammad al-Maliki al-Hasani, ulama kharismatik di Saudi Arabia, ketika ia menunaikan ibadah haji.

Kini Pesantren Al-Manshur dikelola oleh para keturunan Mbah Manshur. Untuk komplek Pondok Sepuh (zawiyah tarekat Naqsyabandiyah

5 Posonan adalah belajar kepada para kiai di suatu pesantren dengan membaca kitab tertentu yang dilakukan pada bulan Ramadlan. 
Khalidiyah) dan Pesantren Al-Manshur Putra diasuh oleh Gus Multazam al-Makki; komplek Pesantren Al-Manshur Putri diasuh oleh K.H. Achmad Djablawi, kakak ipar Mbah Salman; dan komplek Pesantren Al-Manshur Putri II diasuh oleh K.H. Nashrun Minallah, adik kandung Mbah Salman.

Di komplek Pesantren ini, masjid Popongan berada. Manuskripmanuskrip yang dideskripsikan dalam artikel ini tersimpan di ruangan yang berada di bagian belakang masjid. Di dalam ruangan itu, selain manuskrip juga disimpan kitab-kitab berbahasa Arab edisi cetak. Semua manuskrip disimpan dalam satu almari khusus, tetapi tidak disusun secara rapi dan belum tersedia buku katalog, sehingga menyulitkan orang yang ingin mencari dan menemukan satu naskah tertentu yang diinginkan. Lihat gambar 1 berikut ini.
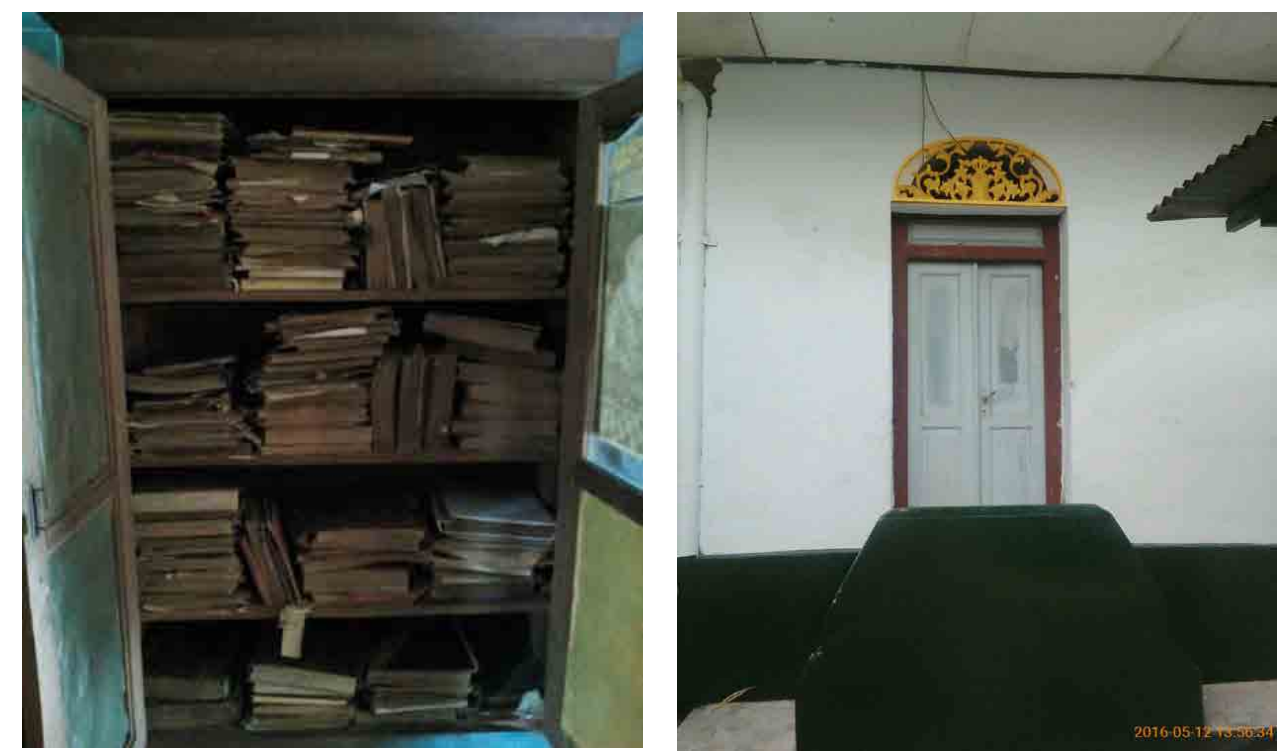

Gambar 1: Almari penyimpanan manuskrip (kiri) dan pintu masuk menuju ruang penyimpanan manuskrip (kanan). Foto: Islah Gusmian.

\section{Kategorisasi Manuskrip Masjid Popongan}

Manuskrip masjid Popongan yang telah didigitalisasi sejumlah 31 manuskrip. Versi digitalnya telah diunggah di web Kementerian Agama Republik Indonesia dengan kode NKK SLO2016 NSR01. SLO merupakan 
kode yang diacu pada tempat, yaitu Solo; 2016 merupakan kode yang mengacu pada tahun dimana digitalisasi dilakukan; NSR merupakan bentuk ringkas dari nama K.H. Nasrun, yaitu nama salah seorang kiai yang mengelola Pesantren Popongan dan merupakan bagian dari keluarga besar Pesantren; adapun angka 01 merupakan nomor urut dari manuskrip yang didigitalisasi.

Pada setiap manuskrip masjid Popongan, tidak selalu berisi satu teks, tetapi juga ada manuskrip yang di dalamnya terdapat beragam teks. Misalnya, manuskrip bernomor NKK SLO2016 NSR11. Manuskrip ini terdiri dari dua teks. Pertama, berjudul Fann al-Rasm, yaitu teks tentang tata cara penulisan al-Qur'an, dan kedua teks berjudul Mandumah al-Suja'i. Keseluruhan manuskrip masjid Popongan ini, memiliki tema, bahasa, dan aksara yang beragam, demikian pula dengan alas yang digunakan.

\section{Tema-Tema dalam Manuskrip Masjid Popongan}

Tema-tema yang ada dalam manuskrip masjid Popongan sangat beragam. Secara umum, bisa dikelompokkan dalam bidang fikih, teologi, tasawuf, tafsir, dan sejarah. Pada masing-masing tema tersebut, terdiri dari banyak teks dengan segala bentuk variannya.

Pertama, tema fikih. Dalam kategori ini, terdapat tema fikih haji, yaitu pada manuskrip dengan nomor NKK SLO2016 NSR03. Manuskrip ini tidak ada judulnya, juga tidak ada keterangan tentang penulis, penyalin, dan tahun penyalinan. Manuskrip ini ditulis di atas kertas modern bergaris. Secara umum, kondisinya baik. Dijilid dengan benang, terdiri 64 halaman, dan berukuran 21 x 17,5 cm, dan ditulis dengan aksara Pegon, bahasa Jawa, dengan khat Naskhi serta menggunakan tinta berwarna hitam. Secara umum, isinya tentang petunjuk dan tata cara menunaikan ibadah haji. Dijelaskan pula hal-hal yang berkaitan dengan kenikmatan-kenikmatan yang dirasakan ketika seseorang menunaikan ibadah haji. 
Masih dalam kategori fiqih, terdapat teks yang berisi tentang hukum waris. Jenis ini, misalnya, terdapat dalam manuskrip dengan nomor NKK SLO2016 NSR05. Manuskrip ini berjudul Fath al-Mu'in Syarb al-Qurrah al'Ain fi Mubimmat al-Din karya Zainuddin bin 'Abdul 'Aziz bin Zainuddin bin 'Ali al-Malibari (w. 1579 M). Teks ini merupakan salinan untuk kepentingan pembelajaran di Pesantren. Mengacu pada informasi yang ada dalam teks, manuskrip ini berasal dari Abdullah Ringin Kediri, kemudian dihadiahkan kepada Muhammad Salman bin Muhammad Muqri, salah satu pengasuh Pesantren Popongan. Manuskrip ini ditulis di atas kertas Eropa. Kondisinya baik dan lengkap, serta dijilid dengan benang. Tebalnya 122 halaman, dan berukuran 24,4 x 11,4 cm. Manuskrip ini ditulis dengan aksara Arab dan Pegon, serta berbahasa Arab dan Jawa, memakai khat Naskbi, dan memakai tinta hitam dan merah.

Kedua, teks-teks yang isinya berkaitan dengan tema gramatikal bahasa dan sastra Arab. Di antaranya adalah manuskrip dengan nomor NKK SLO2016 NSR11. Manuskrip ini terdiri dari dua teks. Teks pertama berjudul Fann al-Rasm, yaitu teks tentang tata cara penulisan al-Qur'an, sedangkan teks kedua berjudul Mandumah al-Suja’i. Teks yang kedua ini merupakan teks di bidang fiqih mazhab Syafi'i yang ditulis dalam bentuk syair (nazam) oleh Syekh al-Allamah Ahmad bin Ahmad bin Muhammad bin Muhammad al-Suja'i (w.1197 H). Judul lengkapnya adalah al-Fawa'id alMizhirah bi Syarb al-Durrah al-Muntadirah. Teks ini disalin ulang oleh K.H. Muhammad Muqri di Solo pada tahun 1912 di atas kertas modern bergaris. Secara umum, kondisinya baik, dijilid dengan benang, terdiri 40 halaman, berukuran $21 \times 16 \mathrm{~cm}$. Bahasa yang digunakan adalah Arab dan Jawa, serta aksara Pegon, dengan khat Naskhi dan menggunakan tinta berwarna hitam.

Selanjutnya, manuskrip dengan nomor NKK SLO2016 NSR07 berjudul Ilmu Nahwu. Manuskrip ini ditulis oleh 'Abdus Salam asy-Syafi'i. Tidak ada keterangan tentang penyalin dan tahun penyalinan. Ditulis di 
atas kertas Eropa. Secara umum, kondisinya baik dan lengkap. Dijilid dengan benang, terdiri 44 halaman dan berukuran $24 \times 18 \mathrm{~cm}$. Ditulis dengan aksara Pegon, berbahasa Jawa dan Arab, dan ditulis dengan khat Naskhi serta memakai tinta berwarna hitam.

Topik serupa dapat dilihat juga pada manuskrip dengan nomor NKK SLO2016 NSR12, berjudul Kitab Nabwu. Teks ini disalin oleh K.H. Muhammad Muqri pada tahun $1341 \mathrm{H}$. Alasnya berupa kertas modern bergaris. Secara umum, kondisinya baik, dijilid dengan benang, terdiri dari 30 halaman, berukuran $21 \times 16 \mathrm{~cm}$, dan ditulis dengan menggunakan aksara Pegon dan Arab, dengan khat Naskhi, serta menggunakan tinta berwarna hitam. Isinya tentang tata bahasa Arab.

Ketiga, manuskrip yang isinya tentang tema tauhid. Di antaranya, manuskrip dengan nomor NKK SLO2016 NSR04 berjudul Ilmu Kalam, Sifat Wajib Dua Pulub. Tidak ditemukan keterangan tentang pengarang, penyalin, dan tahun penyalinan. Manuskrip ini ditulis di atas kertas Eropa, kondisinya baik dan lengkap. Dijilid dengan benang, tebalnya 14 halaman, dan berukuran 20,5 x $16 \mathrm{~cm}$. Manuskrip ini ditulis dengan aksara Pegon dan bahasa Jawa, serta dengan khat Naskhi dan tinta warna hitam. Isinya tentang sifat-sifat yang wajib bagi Allah, sifat mustahil, dan sifat jaiz bagiNya. Disertakan pula uraian tentang makna kerasulan dan kenabian.

Keempat, tema tentang mushaf, tafsir al-Qur'an, dan ilmu al-Qur'an. Pada bagian ini di antaranya adalah manuskrip dengan nomor NKK SLO2016 NSR01, yaitu tentang Mushaf al-Qur'an. Manuskrip ini milik Raden Mas Tumenggung Wiryadiningrat, salah seorang pejabat di kraton Surakarta pada akhir abad 19 M. Secara umum, kondisinya baik, namun pada bagian tengah, sebagian kertasnya berlubang. Alasnya berupa kertas Eropa, dijilid dengan benang, tebalnya 308 halaman, berukuran 39 × 24,5 $\mathrm{cm}$, dan memakai khat Naskhi.

Masih dalam kategori ini, terdapat naskah dengan kode NKK SLO2016 NSR14 berjudul Anwar al-Tanzil karya al-Baidawi dan disalin 
oleh Muhammad Muqri bin Ahmad Kafrawi bin Mahmud. Alasnya berupa kertas bergaris. Secara umun dalam kondisi baik dan terbaca, dijilid dengan benang, tebalnya 32 halaman, dan berukuran $21 \times 16,5 \mathrm{~cm}$. Teksnya ditulis dengan aksara dan bahasa Arab, khat Naskhi, serta memakai tinta hitam. Isinya merupakan tafsir al-Qur'an, dari surah al-Fatihah sampai dengan surah al-Nas. Tapi penyalinannya belum selesai, dan tampaknya penyalinan ini untuk kepentingan bahan mengaji di Pesantren Tremas.

Kelima, tema tentang tasawuf. Di antaranya adalah manuskrip dengan nomor NKKSLO2016 NSR02 berjudul Nadham Nasibat karya Muhammad Rasyid. Alasnya berupa kertas Eropa. Kondisinya baik dan lengkap, dijilid dengan benang. Tebalnya 64 halaman, dan berukuran 21,5 x 17,3 cm., ditulis dengan aksara Pegon dan bahasa Jawa, dengan khat Naskhi. Isinya tentang nasihat bagi para pemuda dalam menjalani kehidupan sehari-hari, baik dalam konteks keluarga maupun sosial kemasyarakatan.

\section{Ragam Bahasa dan Aksara Manuskrip Popongan}

Bahasa dan aksara yang digunakan dalam manuskrip masjid Popongan sangat beragam. Secara umum, bahasa yang digunakan adalah bahasa Arab, Jawa, dan Belanda. Sejumlah manuskrip yang memakai bahasa Arab merupakan manuskrip yang disalin dari kitab-kitab yang ditulis oleh para ulama Timur Tengah. Misalnya, manuskrip nomor NKK SLO2016 NSR05 berjudul al-Qurrah al-'Aini Syarb Fath al-Mu’in, manuskrip nomor NKK SLO2016 NSR11 yang terdiri dari dua teks, yaitu: Fann alRasm dan Mandumah al-Suja'i karya Muhammad al-Maliki disalin oleh K.H. Muhammad Muqri pada 1912, dan manuskrip nomor NKK SLO2016 NSR14 berjudul Anwar al-Tanzil karya al-Baidawi yang disalin oleh K.H. Muhammad Muqri.

Adapun manuskrip-manuskrip yang berbahasa Jawa Pegon secara umum ditulis oleh ulama asal Surakarta. Misalnya, manuskrip nomor NKK SLO2016 NSR04 berjudul Ilmu Kalam, manuskrip nomor NKK SLO2016 
NSR02 berjudul Nadham Nasihat karya Muhammad Rasyid, manuskrip nomor NKK SLO2016 NSR03 berjudul Fiqih Haji, manuskrip nomor NKK SLO2016 NSR06 berjudul Sanad Ilmu ditulis oleh Muhammad Dimyathi ibn Haji Muhammad Amin pada tahun 1955, dan manuskrip nomor NKK SLO2016 NSR08 berisi tentang ilmu gramatika bahasa Arab yang ditulis oleh KH Muhammad Muqri pada tahun 1923.

Adapun manuskrip yang ditulis dengan bahasa Belanda bisa dilihat pada manuskrip nomor NKK SLO2016 NSR17 berjudul Pembagian Harta Warisan karya K.H. Muhammad Muqri. Dalam manuskrip ini beragam bahasa dipakai, yaitu bahasa Arab, Melayu, dan Belanda. Bahasa Arab dan Melayu ditulis dengan aksara Arab dan Pegon sedangkan bahasa Belanda ditulis dengan aksara Latin. Bahasa Belanda dipakai ketika penulis menjelaskan tentang makna kalimat la ilaha illallah.

\section{Jenis Alas Manuskrip Masjid Popongan}

Jenis kertas yang digunakan dalam manuskrip masjid Popongan secara umum terdiri dari dua jenis, yaitu kertas Eropa (Deroche 2005: 57) dan kertas modern bergaris. Pada jenis kertas Eropa, melalui watermark dan countermark yang ada di dalamnya, dapat digunakan untuk memperkirakan tahun penulisan atau penyalinan manuskrip, bila di dalamnya tidak ditemukan data tentang penulisan atau penyalinan teks. Dalam kasus manuskrip masjid Popongan, jenis kertas Eropa dapat dilihat misalnya pada manuskrip nomor NKK SLO2016 NSR01 tentang mushaf al-Qur'an, manuskrip nomor NKK SLO2016 NSR02 berjudul Nadham Nasibat karya Muhammad Rasyid, manuskrip nomor NKK SLO2016 NSR03 berjudul Fiqih Haji, dan manuskrip NKK SLO2016 NSR07 berjudul Ilmu Nahwu karya oleh 'Abd al-Salam asy-Syafi'i.

Jenis kedua adalah kertas modern bergaris. Pada umumnya, manuskrip berbahan kertas modern ini ditulis atau disalin setelah abad 19 M. Manuskrip yang memakai alas kertas bergaris dalam koleksi masjid 
Popongan ini secara umum berukuran ukuran $21 \times 16,5 \mathrm{~cm}$. Sebagiannya merupakan karya salinan para ulama di Pesantren Popongan atas teks-teks berbahasa Arab karya ulama Timur Tengah dan sebagian lagi karya mereka sendiri. Di antaranya adalah manuskrip nomor NKK SLO2016 NSR11 yang berisi dua teks yaitu Fann al-Rasm dan Mandumah al-Suja'i—keduanya disalin oleh K.H. Muhammad Muqri di Solo pada 1912, manuskrip nomor NKK SLO2016 NSR12 berisi tentang gramatika bahasa Arab yang disalin oleh K.H. Muhammad Muqri Solo pada tahun $1341 \mathrm{H}$, dan manuskrip nomor NKK SLO2016 NSR14 berjudul Anwar al-Tanzil karya al-Baidawi disalin oleh K.H. Muhammad Muqri. Perhatikan pada gambar 2, berikut ini.
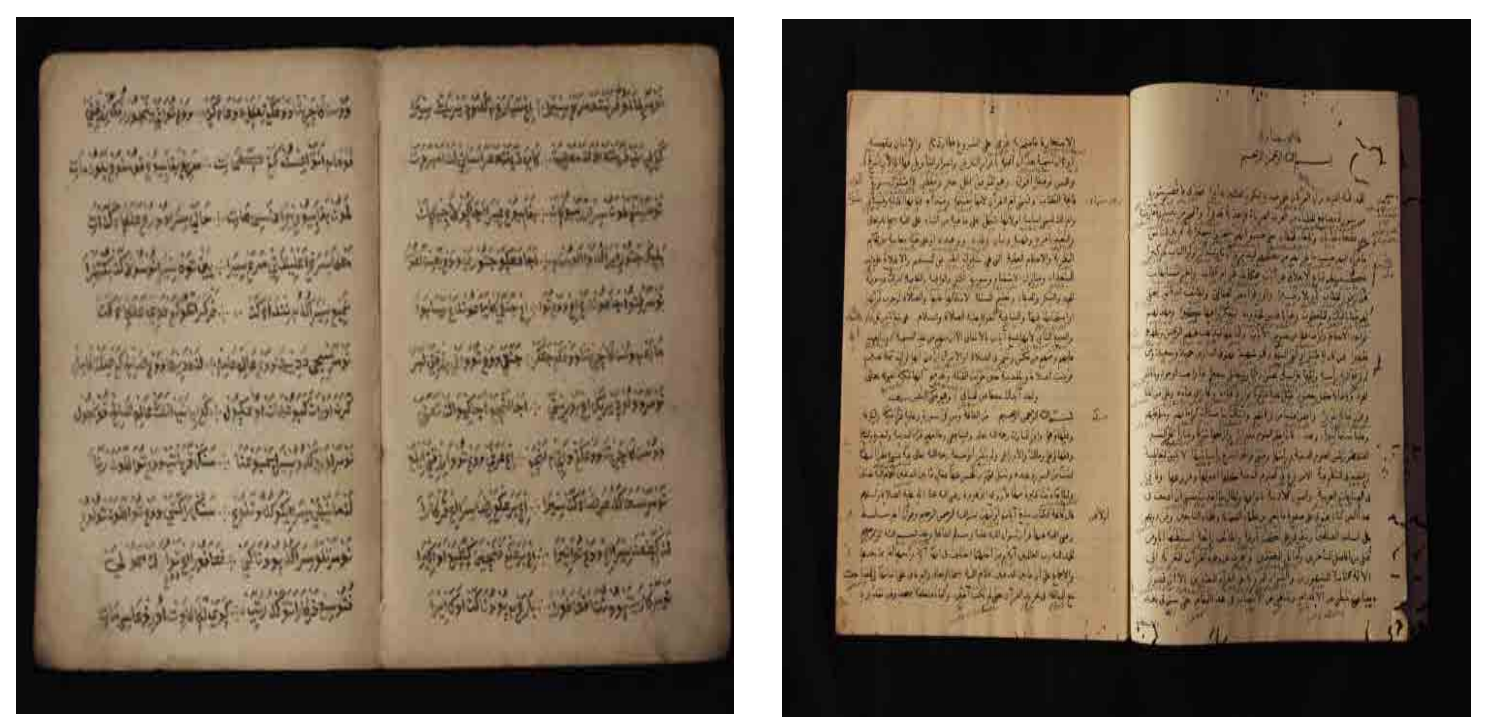

Gambar 2: Jenis kertas Eropa (kiri) dan kertas bergaris modern (kanan).

Foto: Islah Gusmian

\section{Ragam Watermark dan Countermark Manuskrip Masjid Popongan}

Kertas Eropa yang dipakai pada manuskrip masjid Popongan memiliki watermark dan countermark yang beragam. Watermark adalah simbol atau gambar yang terdapat pada sebuah kertas yang dapat dilihat jika kertas tersebut diarahkan ke cahaya. Adapun countermark adalah simbol yang ada 
pada kertas Eropa berbentuk tulisan atau aksara. Keduanya merupakan ciri khas kertas Eropa yang tidak kita temukan pada jenis kertas Dluwang (Permadi 2019) atau kertas modern bergaris.

Keduanya dapat dipakai untuk memperkirakan tahun penulisan atau penyalinan manuskrip bila di dalamnya tidak terdapat informasi terkait waktu penulisan atau penyalinan. Kertas Eropa ini pernah digunakan sebagai alas menulis teks di Nusantara pada era abad 17-19 M. Pada masa itu, jumlah kertas Eropa sangat terbatas, dan biasanya hanya digunakan sebagai alas tulis. Oleh karena itu, usia manuskrip dapat diperkirakan tidak jauh waktunya dengan saat kedatangan kertas tersebut ke Nusantara (Haewood 1981). Keragaman watermark ini mencerminkan periode pembuatan kertas. Dalam kasus manuskrip masjid Popongan, misalnya terdapat watermark jenis Pro Patria bergambar Singa membawa pedang dan prajurit membawa tombak dan Pro Patria bergambar liontin mahkota dengan Singa membawa pedang. Keduanya menunjukkan bahwa kertas jenis ini dibuat pada era tahun 1600-an. Lihat pada gambar 3 berikut ini.
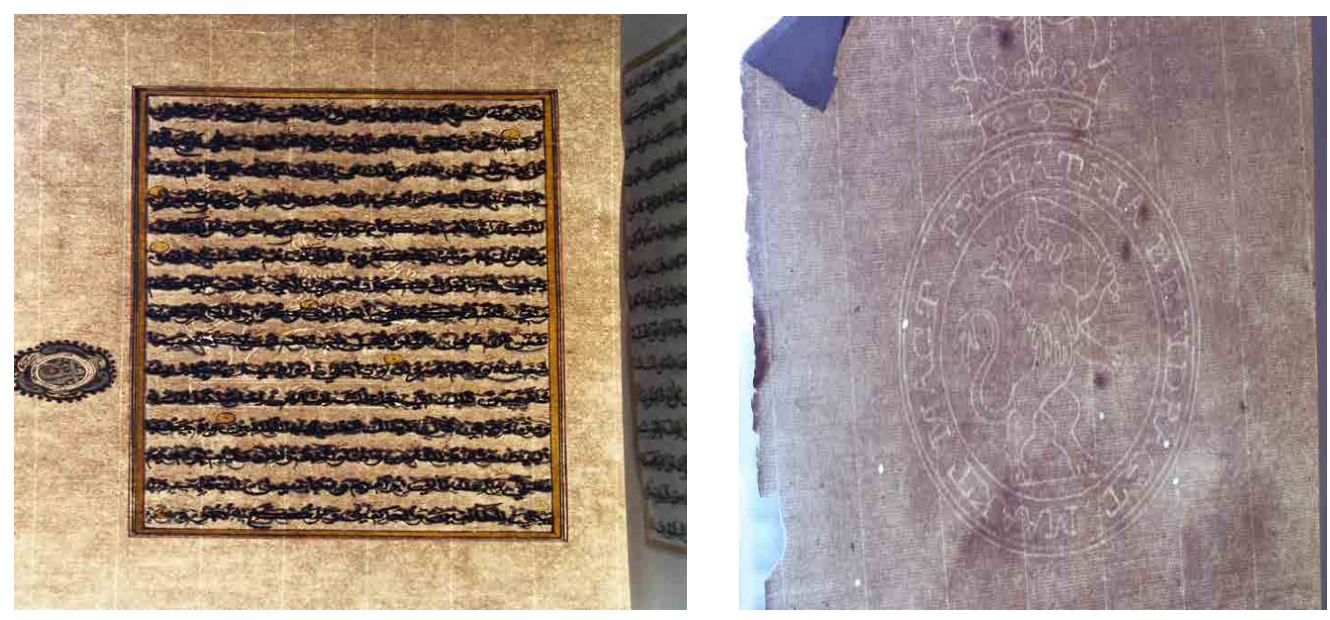

Gambar 3: Dua jenis watermark manuskrip koleksi masjid Popongan. Foto: Islah Gusmian

Jenis kertas Eropa pada manuskrip masjid Popongan juga memiliki countermark. Di antaranya dalam bentuk tulisan GIW PANNEKOEN yang menyertai watermark jenis Concordia bergambar Singa membawa pedang 
dalam liontin dengan mahkota. Jenis ini terdapat pada manuskrip nomor NKK SLO2016 NSR45. Lihat pada gambar 4 berikut ini.

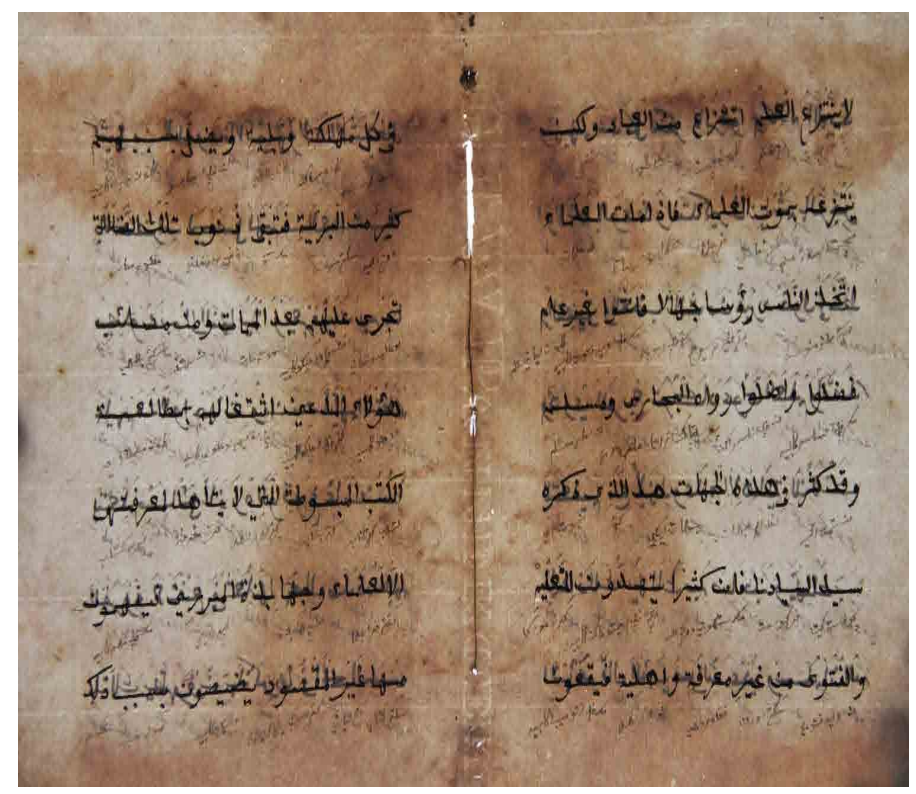

Gambar 4: Countermark dalam bentuk tulisan GIW PANNEKOEN.

Foto: Islah Gusmian

\section{lluminasi dan Ilustrasi dalam Manuskrip Masjid Popongan}

Iluminasi dan ilustrasi lazim ditemukan dalam naskah klasik keagamaan (Kumar and McGlynn 1996). Iluminasi adalah hiasan di dalam naskah-naskah berupa hiasan bingkai yang biasanya terdapat pada halaman awal, tengah, dan mungkin juga pada halaman akhir. Sedangkan ilustrasi adalah hiasan yang mendukung dan menjadi penjelas atas teks (Mulyadi 1994). Menurut Gallop dan Arps, iluminasi dalam bahasa Indonesia berpadanan dengan istilah seni sungging, dan di Yogyakarta disebut renggan wadana (Gallop and Arps 1991); (Mu'jijah 2000).

Keduanya ini dihadirkan sebagai penghias dan cara untuk menarik perhatian dan mempermudah dalam menguraikan masalah. Jenis iluminasi yang indah banyak dijumpai pada manuskrip mushaf al-Qur'an, Barzanji, Babad, dan yang lain. Manuskrip yang diinisiasi kraton atau kerajaan 
biasanya memiliki iluminasi yang indah dan mewah, baik dari segi warna maupun bentuknya. Sedangkan manuskrip salinan yang dipakai belajar di pesantren biasanya iluminasinya sederhana. Misalnya bermotif garis-garis dan kotak, atau sulur daun yang sederhana. Dalam konteks manuskrip masjid Popongan juga demikian. Manuskrip mushaf milik Raden Mas Tumenggung Wiryodiningrat yang ada pada masjid Popongan memiliki iluminasi yang indah. Mushaf ini berasal dari Trengganu. Sedangkan pada teks Matn al-Sanusiyah iluminasinya sederhana, karena manuskrip ini dipakai sebagai bahan belajar di pesantren. Lihat pada gambar 5 berikut ini.
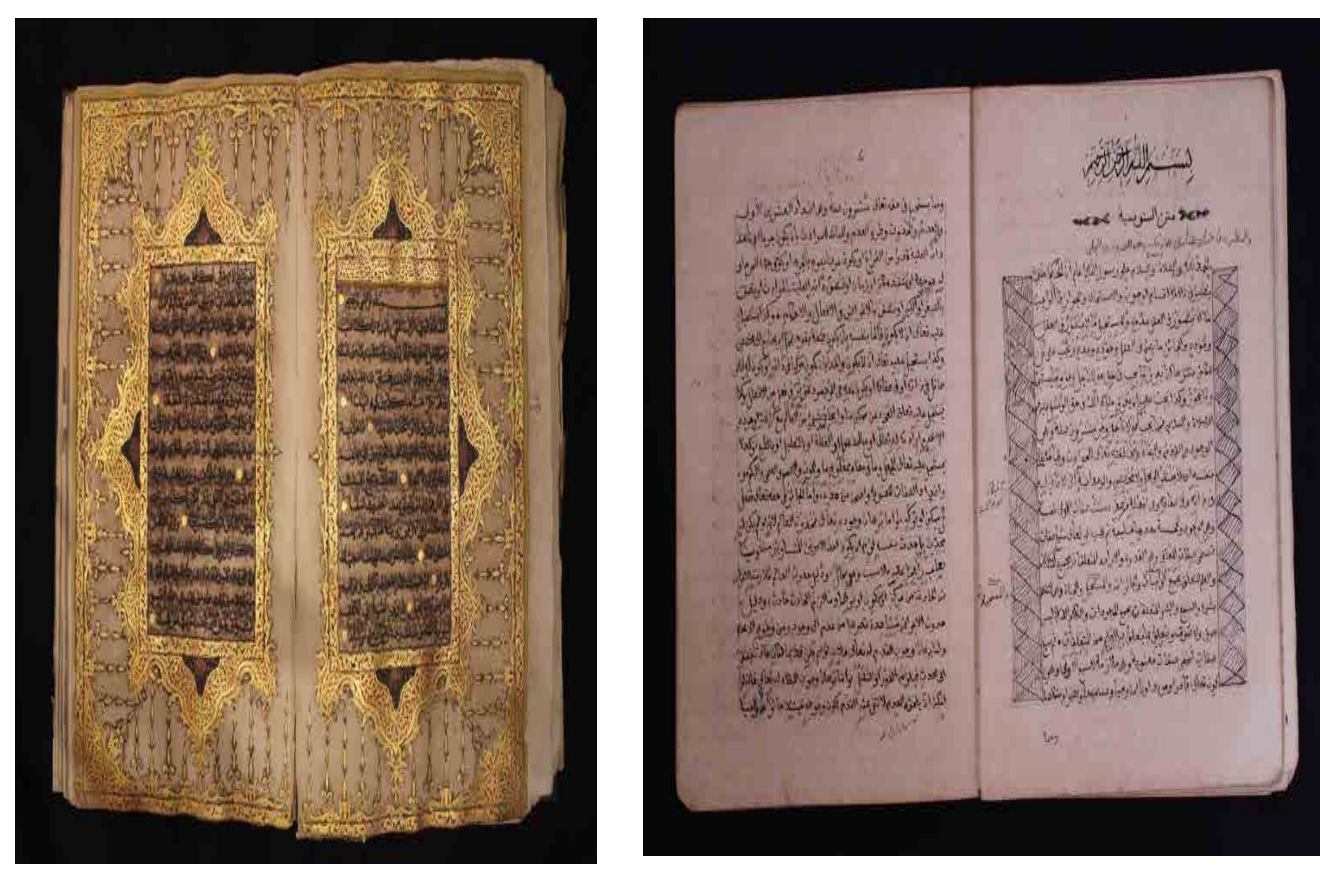

Gambar 5: iluminasi mushaf (kiri) dengan ornamen yang mewah, dan iluminasi Matn al-Sanusiyah yang sederhana (kanan).

Foto: Islah Gusmian

Ilustrasi dalam manuskrip keagamaan biasanya dipakai untuk menjelaskan materi atau topik yang dibahas. Oleh karena itu, ia merupakan kesatuan fungsi dengan teks. Hal yang demikian ini juga terjadi pada manuskrip masjid Popongan. Ada sejumlah ilustrasi yang dipakai untuk memberikan penjelasan tambahan dalam bentuk gambar atau untuk memudahkan suatu pembahasan yang ada dalam teks dalam bentuk warna, 
tabel, bagan alur ataupun gambar yang memiliki makna simbolis. Misalnya, terdapat bentuk bagan dan garis yang dipakai untuk menjelaskan silsilah, warna yang dipakai untuk menjelaskan jenis darah haid yang dialami perempuan, dan tabel yang dipakai untuk menjelaskan keragaman topik dalam gramatikal bahasa Arab. Lihat gambar 6 berikut ini.
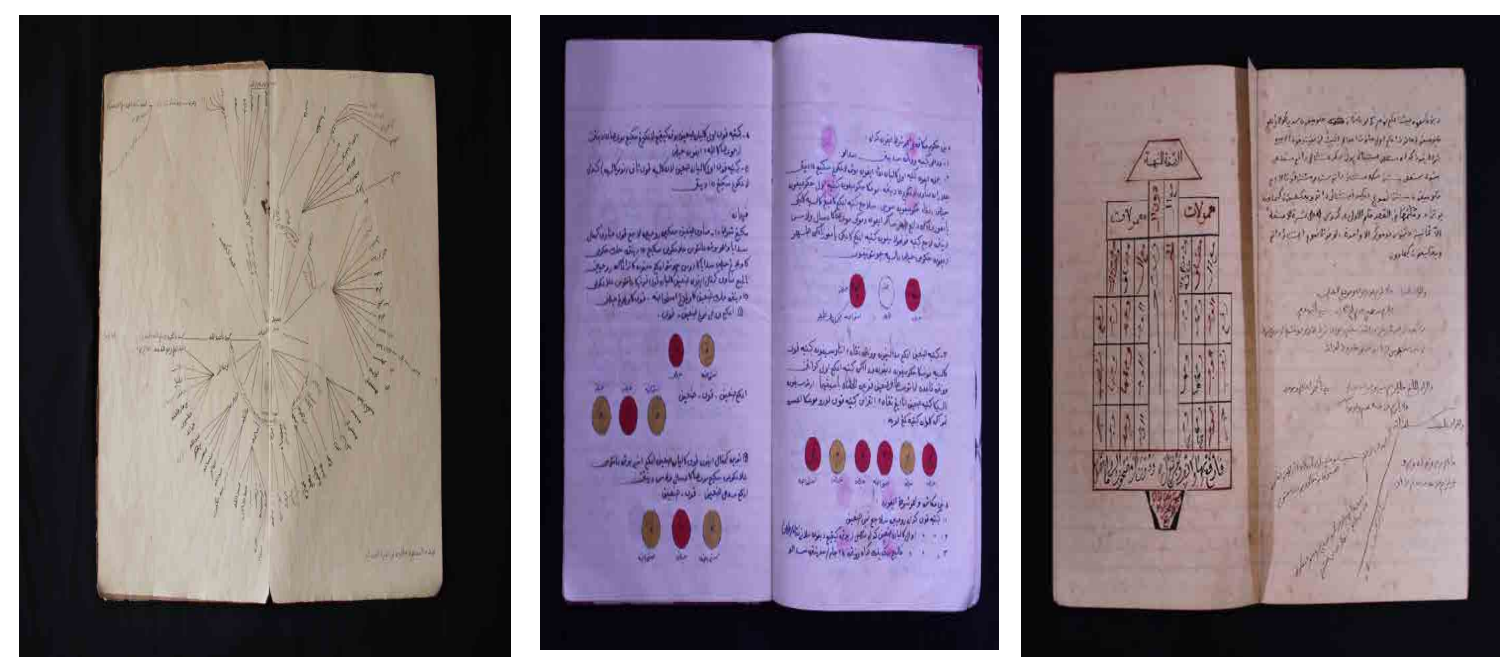

Gambar 6: ilustrasi dalam bentuk garis (kiri), warna (tengah) dan bagan (kanan).

Foto: Islah Gusmian

\section{Sampul Manuskrip masjid Popongan}

Manuskrip-manuskrip keagamaan di Nusantara memiliki bentuk sampul yang beragam, baik dari segi bahan dan modelnya. Secara umum, terbuat dari kulit binatang dan kertas karton (Ageng Wuri Rezeki A 2019). Dalam kasus manuskrip masjid Popongan, bahan dasar sampulnya beragam, yaitu kulit binatang, kertas karton dengan ukuran tebal, dan kertas modern. Hiasan dan motifnya beraneka ragam, yaitu hiasan timbul dalam bentuk batik dengan motif bunga tanpa warna, motif batik dengan warna emas, tanpa hiasan dengan bahan kertas karton ukuran tebal, dan sampul kertas modern dengan ukuran tipis bermotif batik.

Manuskrip dengan sampul berbahan dasar dari kulit, kondisinya tidak utuh karena mengalami kerusakan di beberapa bagian. Warnanya hitam atau kecoklatan. Motif hiasan yang digunakan berupa hiasan timbul tanpa warna (blind stamping) dan dilapisi tinta emas. Ada juga yang menggunakan

DINIKA, Volume 4, Number 2, May - August 2019 
sampul berbahan dasar kulit binatang dan polos tanpa motif hias. Sebagian yang lain ada model sampul yang di bagian belakang memiliki penutup seperti pada amplop atau flap (Plomp 1993). Sampul-sampul tersebut dilapisi dengan kertas tebal. Hal ini dilakukan agar penyampulan lebih kuat, rapi, dan manuskrip bertahan lebih lama.

Di samping berbahan kulit, dijumpai pula sampul berbahan kertas karton dan sampul buku bermotif batik. Sampul jenis ini digunakan untuk manuskrip yang usianya belum tua, atau dibawah 100 tahun. Model ini juga digunakan untuk penyampulan ulang terhadap manuskrip berbahan kertas Eropa maupun kertas dluwang yang sampulnya sudah rusak. Untuk memperkuat sampul, di sebagian manuskrip ada yang dilaminasi dengan plastik pada bagian depan dan belakang. Hal ini dilakukan agar sampul lebih tahan lama dan tidak mudah kotor. Penyampulan ulang terhadap manuskrip-manuskrip ini juga bertujuan untuk memberi identitas manuskrip sesuai judulnya, sehingga memudahkan orang dalam pencariannya. Lihat gambar 7 berikut ini.
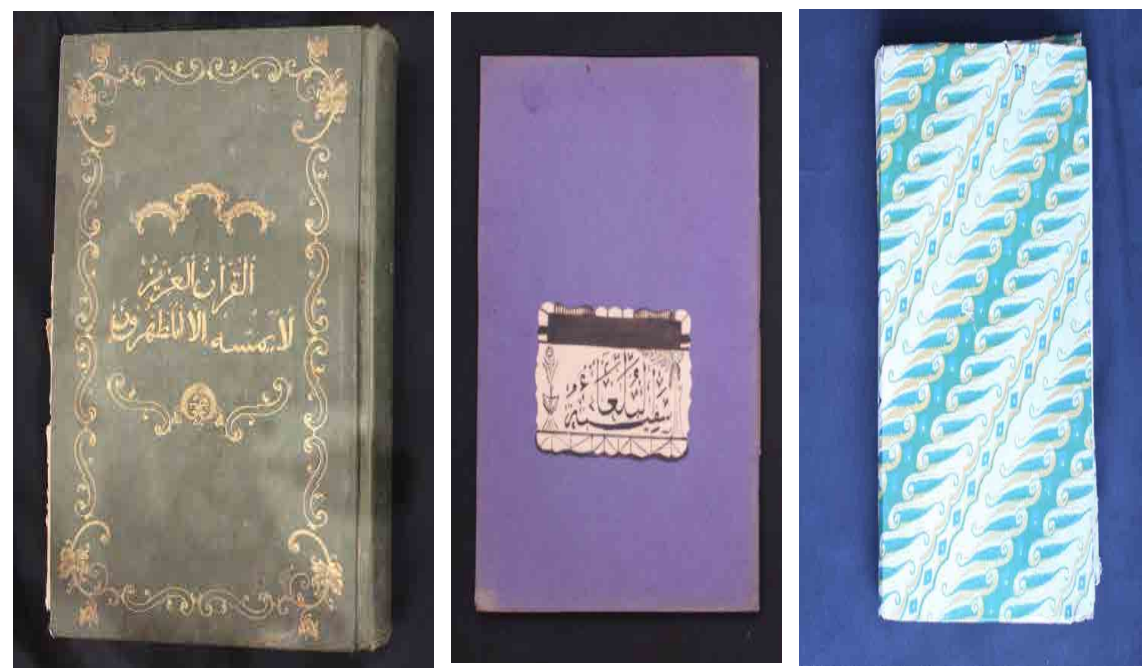

Gambar 7: Aneka ragam sampul manuskrip koleksi masjid Popongan.

Foto: Islah Gusmian 


\section{Asal-Usul Manuskrip masjid Popongan}

Mengacu pada data-data internal yang ada dalam teks, sejarah dan asal-usul manuskrip masjid Popongan beragam dan berbeda-beda. Sebagian besar, merupakan catatan-catatan dan salinan atas kitab-kitab berbahasa Arab yang ditulis oleh ulama Timur Tengah. Penyalinan ini dilakukan oleh K.H. Muhammad Muqri untuk kepentingan belajar di pesantren.

Ditemukan suatu catatan bahwa teks-teks tersebut lahir ketika Muhammad Muqri belajar agama di pesantren Tremas Pacitan Jawa Timur (Fachir 2010). Misalnya, dalam manuskrip karya Muhammad Dimyathi bin Abdul Karim Surakarta, berjudul Lawami' al-Burban wa Qawati' al-Bayan Lizujri al-Awam min al-Huðban, salah seorang santri di Pesantren Tremas, terdapat informasi bahwa penyalin teks tersebut adalah K.H. Muhammad Muqri bin Kafrawi bin Mahmud, salah seorang santri di Pesantren Tremas. Informasi ini terletak di halaman awal teks tersebut. Hal yang demikian kita jumpai di berbagai teks yang lain (lihat pada gambar 9). Tampaknya Muhammad Muqri merupakan santri yang rajin menyalin teks-teks dari Timur Tengah dan karya para gurunya serta memiliki kebiasaan memberikan catatan dan identitas dirinya disertai nama pesantren di mana ia belajar ketika menulis kitab ataupun catatan atas suatu teks. Selain belajar di Pesantren Tremas, K.H. Muhammad Muqri juga pernah belajar di berbagai pesantren yang lain. Misalnya, di Pesantren Manbaul Ulum Surakarta.

DINIKA, Volume 4, Number 2, May - August 2019 


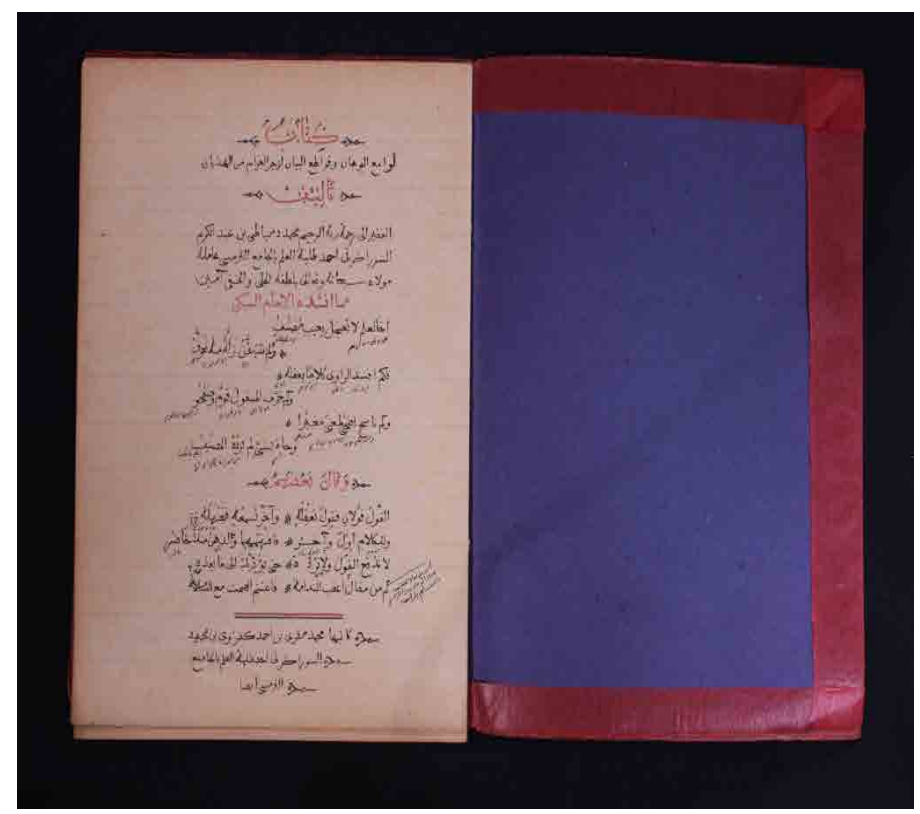

Gambar 8: Salah satu halaman dimana K.H. Muhammad Muqri menuliskan identitas dirinya.

Foto: Islah Gusmian

Kedua, teks-teks yang berisi tentang catatan dan tulisan para kiai di pesantren Popongan pada era akhir abad 19 M. Di antaranya, catatan mengenai silsilah para kiai Popongan, silsilah tarekat Naqsyabandiyah, catatan tentang kematian dan kelahiran K.H. Muhammad Manshur, teks khutbah dan teks-teks fiqih.

Selain dua jenis di atas, terdapat manuskrip yang berasal dari luar pesantren Popongan. Manuskrip jenis ini, patut diduga merupakan manuskrip yang dibawa para pendiri pesantren Popongan dari tempat atau kiai di mana ia belajar. Jenis ini bisa dilihat, misalnya pada manuskrip nomor NKK SLO2016 NSR05 berjudul Fath al-Mu'in Syarb al-Qurrah al-'Ain fi Mubimmat al-Din karya Zainuddin bin 'Abdul 'Aziz bin Zainuddin bin 'Ali al-Malibari (w. 1579 M). Manuskrip ini dimiliki oleh Abdullah, Tegalsari, Ringin Agung, Kediri, kemudian dihadiahkan kepada Muhammad Salman bin Muhammad Muqri, salah seorang pengasuh Pesantren Popongan. ${ }^{6}$ tersebut.

6 Kesimpulan ini diperoleh dari informasi tertulis yang ada di bagian awal teks 
Di masjid Popongan ini terdapat pula manuskrip mushaf Al-Qur'an milik Kanjeng Bendara Raden Mas Tumenggung Wiryadiningrat. ${ }^{7}$ Ia seorang penguasa di Kraton Surakarta pada era abad 1900 an. Keberadaan manuskrip mushaf di masjid Popongan ini, patut diduga bahwa pada era itu telah terjadi hubungan yang intens antara para ulama di pesantren Popongan dengan para penguasa di kraton Surakarta.

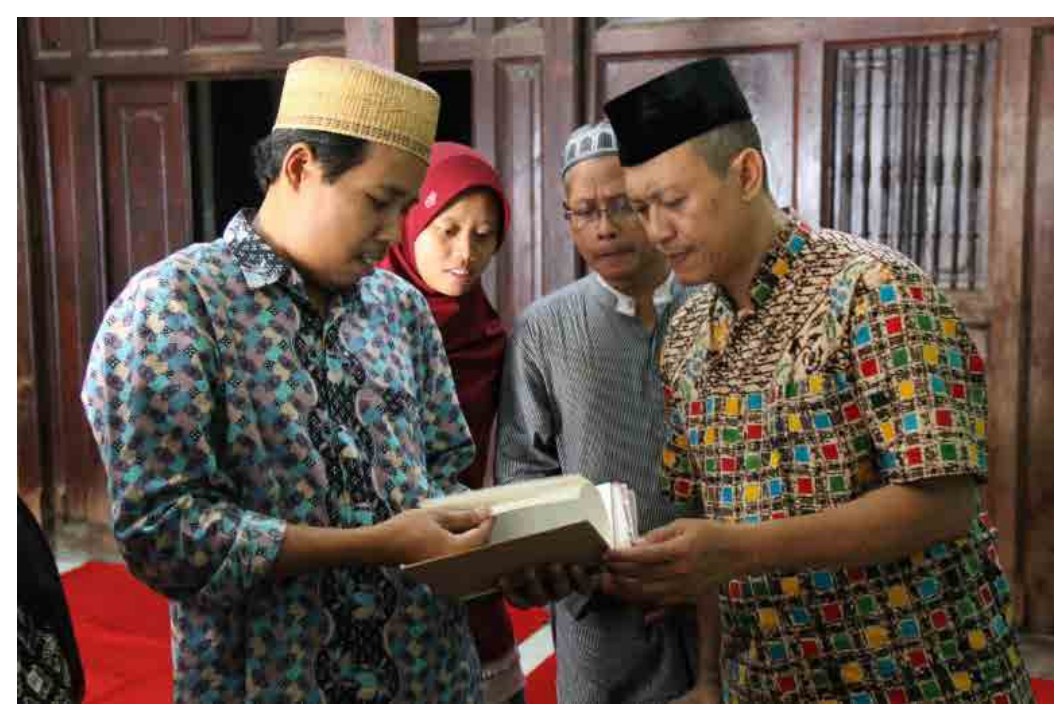

Gambar 8: Penulis ketika melakukan konservasi manuskrip koleksi Masjid Popongan bersama para ulama.

Foto: Islah Gusmian

\section{Kesimpulan}

Secara umum, kondisi fisik manuskrip koleksi Popongan cukup baik, utuh dan terbaca, tapi di beberapa manuskrip di antaranya mengalami kerusakan karena usianya yang tua. Pemeliharaan dan penyimpanan manuskrip masjid Popongan masih sederhana. Manuskrip-manuskrip tersebut disimpan dalam lemari dengan saling bertumpukan antar manuskrip, sehingga manuskrip yang memakai kertas Eropa menjadi

7 Bukti kepemilikan ini diacu pada satu informasi tertulis yang ada di bagian awal dari manuskrip mushaf tersebut yang ditulis memakai aksara Pegon. Patut diduga, penulisan ini dilakukan terpisah dari penulisan manuskrip mushaf. Sebab, jenis dan karakter aksara atau khat yang dipakai berbeda dengan khat yang dipakai dalam penyalinan mushaf.

DINIKA, Volume 4, Number 2, May - August 2019 
lembab dan lapuk. Untuk manuskrip berbahan kertas modern bergaris kondisinya baik karena usianya yang belum terlalu tua.

Manuskrip-manuskrip masjid Popongan terdiri dari berbagai bentuk, yaitu teks salinan, cacatan-catatan ketika belajar di pesantren, dan karya-karya yang ditulis secara mandiri oleh para ulama di pesantren Popongan. Keberagaman bidang ilmu yang ditulis, aksara dan bahasa yang digunakan mencerminkan tentang sejarah intelektual pesantren dan transmisi keilmuan yang terjadi di pesantren.

Pemetaan yang dilakukan dalam artikel ini menunjukkan bahwa pesantren dan santri merupakan subjek penting di dalam proses pembangunan ilmu-ilmu keislaman di Nusantara. Darinya kita juga mengerti bahwa pesantren memiliki peran penting dalam islamisasi serta transmisi keilmuan Islam dari masa ke masa di negeri ini, tidak terkecuali di kawasan Surakarta.]

\section{Daftar Pustaka}

A, Ageng Wuri Rezeki. 2019a. "Kekhasan Penjilidan Buku Kuno Racikan Indonesia." Akarpadinews. 2019. http:/ /akarpadinews.com.

- 2019b. "Kekhasan Penjilidan Buku Kuno Racikan Indonesia." AkarpadiNews. 2019. http:/ / akarpadinews.com.

“Biografi Simbah K.H. Salman Dahlawi.” 2019. Blogspot. 2019. http:// ponpesalmanshur.blogspot.co.id.

Bruinessen, Martin Van. 1992. Tarekat Naqsyabandiyah di Indonesia. Bandung: Mizan.

Chernik, Barbara E. 1994. Introduction to Library Services. Englewood, Colorado: Libraries Unlimited.

Deroche, Francois. 2005. Islamic Codicology: An Introduction to the Study of Manuscript in Arabic Script. London: Al-Furqan Islamic Heritage Foundation No 102. 
Direktorat Kebudayaan, Pariwisata, Pemuda dan Olahraga, Deputi Bidang Sumber Daya Manusia dan Kebudayaan. 2006. Studi Penyelamatan Kekayaan Budaya. Jakarta: Bappenas.

Drewes, G.W.J. 1969. The Admonitions of Seh Bari. The Hague, Netherlands. Ekajati, Edi S., and Undang A. Darsa. 1999. Katalog Induk Naskah-naskah Nusantara, Jilid 5 A Jawa Barat: Koleksi Lima Lembaga. Jakarta: Yayasan Obor Indonesia- Ecole Francaise D'Extreme-Orient.

Fachir, A.M., ed. 2010. Jauh di Mata Dekat di Hati: Potret Hubungan IndonesiaMesir. Kairo: KBRI Kairo.

Fadliah. 2010. "Pelestarian Naskah Kertas Eropa di Perpustakaan Fakultas Ilmu Pengetahuan Budaya Universitas Indonesia."

Fahriati. 2009. "Kajian terhadap Watermark dan Countermark dalam Naskah Klasik Keagamaan."

Gallop, Anmabel The, and Bernard Arps. 1991. Golden Letter Writing Tradition: The Britis Library. Jakarta: Yayasan Lontar.

Girardet. 1983. Descriptive Catalogue of the Javanese Manuscripts and Printed Book in the Main Libraries of Surakarta. Wiesbaden: Franz SteinerVerlaq GMBH.

Gusmian, Islah. 2004. "Al-Quran dalam Pergumulan Muslim Indonesia." Jurnal Tasywirul Afkar 8.

—. 2015. "Warisan Islam Nusantara: Tentang Manuskrip dan Aksara Pegon.” In Gerakan Kultural Islam Nusantara, edited by Jibril FM. Yogyakarta: JNM.

Haewood, Edwardm MA. 1981. Monumenta Chart Papyrace, Historian Illustrantia, Watermarks I, Mainly of the 17th and 18th Centuries. Inggris: The Paper Publication Society.

Keagamaan, Puslitbang Lektur. 1999. Katalog Naskah Kuno. Edited by 2 Jilid. Jakarta.

Kebudayaan, Departemen Pendidikan dan. 1972. Katalogus Koleksi Naskah Melayu Museum Pusat. Jakarta: Departemen Pendidikan dan Kebudayaan.

Kumar, Ann, and John H. McGlynn. 1996. Illuminations the Writing Tradition of Indonesia. Jakarta: The Lontar Foundation. 
Loir, Hendrichambert, and Oman Fathurahman. 1999. Panduan Koleksi Naskah-naskah Indonesia Sedunia. Jakarta: Yayasan Obor Indonesia.

Lubis, Nabilah. 2007. Naskah, Teks, dan Metode Penelitian Filologi. Jakarta: Puslitbang Lektur Keagamaan Badan Litbang dan Diklat Depag.

Misky, Dudy. 2007. Ensiklopedi Teknologi Digital. Jakarta: Restu Agung.

Mu'jijah. 2000. "Pemaknaan Simbol Ilustrasi dalam Sebuah Teks Mistik: Kajian Kodikologis Disertai Edisi Teks.” Universitas Indonesia.

Mukhlis Paeni, dkk. 2003. Katalog Induk Naskah-naskah Nusantara: Sulawesi Selatan. Jakarta: Gajah Mada University Press.

Mulyadi, Sri Wulan Rujiati. 1994. "Kodikologi Melayu di Indonesia." Depok: Lembar Sastra Edisi Khusus No. 24.

Permadi, Tedi. 2019. "Cara Membuat Kertas Daluang." Daluang. 2019. http://daluang.com/cara-membuat-kertas-daluang/.

Plomp, M. 1993. "Traditional Book Binding from Indonesia Materials." Journal of the Royal Institute of Linguistic and Anthropology 149 (3).

Saksono, Widji. 1995. Mengislamkan Tanah Jawa: Telaah atas Metode Dakwah Walisongo. Mizan.

Sardjoko, Subandi. 2007. "Teori Sejarah Dan Filologi: Kebijakan Penyelamatan, Pemeliharaan dan Penelitian Naskah Kuno." Puncak, Bogor: Disampaikan pada Workshop Konservasi naskah diadakan Puslitbang Lektur Keagaman Badan Litbang dan Diklat Depag.

Sartono Kartodirjo, dkk. 1975. Sejarah Nasional Indonesia V, VI. Jakarta: Departemen P \& K.

Siti Baroroh Baried, dkk. 1985. Pengantar Teori Filologi. Jakarta: Pusat Pembinaan dan Pengembangan Bahasa Departemen Pendidikan dan Kebudayaan.

Soebadiyo, Haryati. 1982. "Agama sebagai Sasaran Penelitan Filologi." In Pengetabuan Budaya, Ilmu-ilmu Sosial dan Pengkajian Masalah-masalah Agama, edited by Parsudi Suparlan. Jakarta: Pusat Penelitian dan Pengembangan Lektur Agama Badan Litbang Agama.

Sr, C.F. Winter, and R.Ng. Ranggawarsita. 2003. Kamus Kawi-Jawa. Gajah Mada Press. 
Sunyoto, Agus. 2011. Wali Songo, Rekonstruksi Sejarah yang Disingkirkan. Jakarta: Trans Pustaka.

DINIKA, Volume 4, Number 2, May - August 2019 